\title{
Study on the Construction of the Service System for Intellectual Property in Chinese Universities Under the New Normal of Innovation-Driven
}

\author{
Xin Wen, Min Zhou, Zixiang Wang \\ College of Economics and Management \\ Southwest Petroleum University \\ Chengdu, China
}

\begin{abstract}
Under the new normal of innovation-driven, with continues emergence of new business formats, new technologies and new disciplines, it is of great theoretical and practical significance to analyze the connotation and practice mode of the service system for intellectual property in colleges and universities. According to the viewpoint of the system theory, the service system for intellectual property in colleges and universities can be divided into the information service system, the operation service system, the education \& training service system, the financial service system and the intermediary service system. Each service system has its own system and also interrelated with other systems. On the basis of analyzing the defects of each subsystem of the service system for intellectual property in colleges and universities, some countermeasures and suggestions are put forward, such as promoting the professionalization of management service of intellectual property, perfecting the comprehensive operation system of intellectual property, innovating the mode of the cooperation of government, industry, university and research institute, overall establishing the service system of high-quality talents and the propaganda \& education system of intellectual property in colleges and universities.
\end{abstract}

Keywords-Innovation-Driven; Systems Theory; Intellectual Property in Colleges and Universities; Service System

\section{INTRODUCTION}

Driven by the "National 13th five-year plan for the protection and application of intellectual property", China has made great development in the field of intellectual property. With the promotion of the strategy of innovation-driven development and the continuous emergence of "new industrial subjects", the intellectual property service industry is facing with new development opportunities as well as new challenges. As an integral part of the national innovation system, colleges and universities have the functions of creating knowledge, spreading knowledge and applying knowledge. Its function of applying knowledge is mainly reflected in transforming knowledge into technology and products, and directly participating in the creating of social wealth, which is not only the need for social development in the age of knowledge-based

Project funded by Subsidized by Sichuan Oil \& Gas Development Research Center (Sichuan oil \& gas scienceSKA19-02)

Project funded by Humanities and Social Science Project 239 of Southwest Petroleum University economy, but also the need for the development of colleges and universities themselves. The new situation has put forward new demands for the service system of intellectual property in Colleges and universities.

\section{The Connotation And Framework of The SER Vice SYSTEM FOR INTELLECTUAL PROPERTY IN COLLEGES AND UNIVERSITIES}

From the perspective of system theory, the service system of intellectual property in colleges and universities is a multi-dimensional system consisting of colleges and universities, governments, enterprises, intermediaries, parks, achievements of intellectual property, talents, technology, capital, markets and operating platforms, with each part interrelating and interacting with each other. Therefore, this paper aims to agglomerate innovative elements, unimpeded and promote the transformation of the value chain, accelerate the establishment of the public service system of intellectual property rights in colleges and universities, and promote the healthy development of intellectual property rights in colleges and universities based on system theory.

Based on the systematic analysis of the transformation of intellectual property in colleges and universities, the service system of intellectual property in colleges and universities is divided into multiple levels, such as the information service system, the operating management system, the intermediary service system, the financial service system and the education $\&$ training system.( Fig.1)

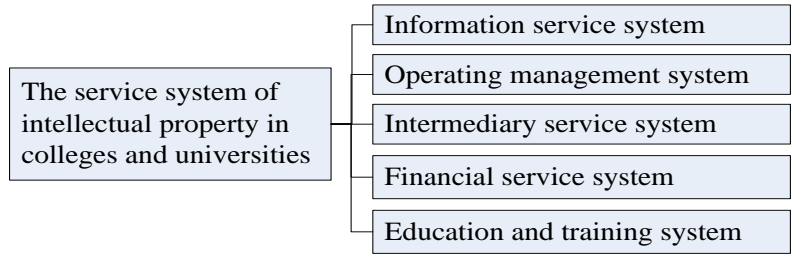

Fig.1. Composition of the Service System of Intellectual Property in Colleges and Universities

The information service system is a unified whole or system composed of various elements of information service for intellectual property in accordance with certain principles and guaranteed by relevant policies and regulations for its 
smooth development, with meeting the needs of intellectual property information of specific strata as the goal, and the publication, integration, analysis, retrieval, translation, database construction and information system development of intellectual property information as the main contents. The operating management system mainly includes investment mechanism, operating mechanism, management mechanism, incentive mechanism and protection mechanism. The intermediary service system includes legal rights protection, advisory services and agency services for intellectual property. The intellectual property financial service system mainly involves intellectual property pledge financing, patent insurance market and capitalization of intellectual property. The education and training system for an intellectual property involves higher education, vocational qualification training, high-end practical training, etc.

\section{PROBleMS IN THE SERVICE SYSTEM OF INTELLECTUAL PROPERTY IN COLLEGES AND UNIVERSITIES IN CHINA}

\section{A. The information service system}

From the construction subject of the information service platform for intellectual property in colleges and universities, it can be divided into three modes: independently building an information service center, establishing union of intellectual property information service centers in Colleges and universities, and establishing integrated operation platform of intellectual property rights. At present, only some universities, such as Zhejiang University, Jiangsu University, Nanjing University and Beijing Jiaotong University, have set up special information service platforms for intellectual property, some universities such as Hunan University have set up technology transfer centers, intellectual property research institutes, and the information service of most other universities are affiliated to the scientific research departments and the university science parks.

In general, the market-oriented service of intellectual property information in colleges and universities in China is in the early stage, the informationization service level of intellectual property in colleges and universities in Western China is lower than that in eastern China and developed provinces and cities, with limited types of information service subjects, traditional service modes, few high-level service institutions and narrow channels for cooperation between intellectual property and libraries in colleges and universities, inadequate development of service system tools, resources sharing and interconnection, and service quality needing to be improved.

\section{B. The operating management system}

Firstly, the input mechanism of operation management in colleges and universities is not perfect. From the actual situation of the transformation of intellectual property achievements in colleges and universities, the obstacles in the input mechanism are mainly reflected in the following aspects: insufficient R\&D expenditures blocked investment subjects and channels.

Statistical data of the National Bureau of Statistics from 2008 to 2017 show that research and experimental development expenditure in China is showed a rising trend year by year, but the growth of expenditure of higher institutes is significantly lower than that of national expenditure, with the proportion of expenditure of higher institutes in national expenditure decreasing from $8.45 \%$ in 2008 to $6.84 \%$ in 2016 and slightly rising to $7.19 \%$ in 2017. From 2008 to 2014, the growth of expenditure of higher institutes showed a fluctuating downward trend, with rising from $19.99 \%$ in 2009 to the highest of $27.57 \%$ in 2010 , then declining to $4.83 \%$ in 2014 , and from 2015 to 2017, it showed a fluctuating upward trend, reaching 18.07\% in 2017.( Fig. 2 and Fig. 3)

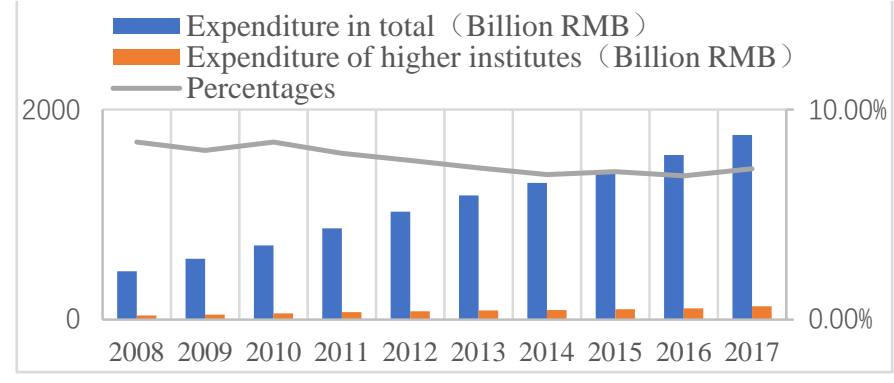

Fig.2. R\&D Expenditure Input in China from 2008 to 2017

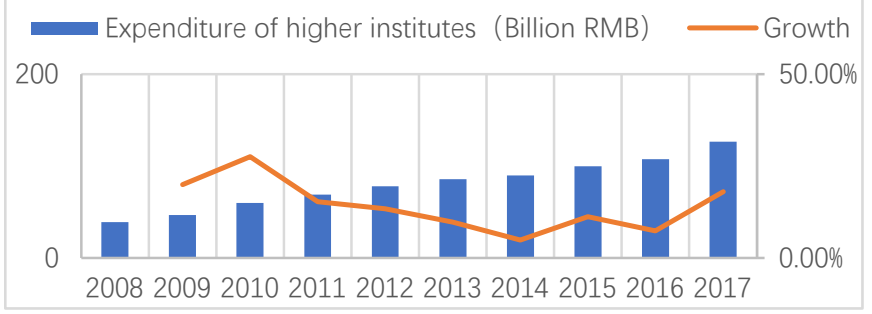

Fig.3. Expenditure of Higher Institutes and Growth from 2008 to 2017

Secondly, the operating mechanism is not perfect. At present, the intellectual property operation with universities as the main body mainly includes three modes: technology licensing office, the science faculty and direct cooperation with enterprises. The main problems existing in the operating mechanism of intellectual property are as follows: inaccurate transformation process, weak transformation mechanism and lack of scientific pricing principles.

According to the data from China Patent Survey Report 2018, more than $80 \%$ of patentees in colleges and universities have the rate of technology transfer less than $10 \%$, with more than the accumulative total of $99 \%$ have the rate of technology transfer less than $50 \%$, and more than $50 \%$ of patentees in $\mathrm{R} \& \mathrm{D}$ institutions have the rate of technology transfer less than $10 \%$. Overall, the rate of technology transfer of patentees in $\mathrm{R} \& \mathrm{D}$ institutions is slightly higher than that in colleges and universities.

TABLE I. THE RATE OF TECHNOLOGY TRANSFER OF PATENTEES IN UNIVERSITIES AND R\&D INSTITUTIONS (UNIT: \%)

\begin{tabular}{|l|c|c|c|}
\hline & University & R\&D Institution & Total \\
\hline Less than $10 \%$ & 80.1 & 50.8 & 70.4 \\
\hline $10 \%-20 \%$ & 14.1 & 11.9 & 13.4 \\
\hline $20 \%-30 \%$ & 3.8 & 12.3 & 6.6 \\
\hline $30 \%-40 \%$ & 0.9 & 3.8 & 1.8 \\
\hline $40 \%-50 \%$ & 0.6 & 2.8 & 1.3 \\
\hline $50 \%-60 \%$ & 0.2 & 11.7 & 4 \\
\hline
\end{tabular}




\begin{tabular}{|l|c|c|c|}
\hline \multicolumn{5}{|c|}{ Cont. to TABLE I. } \\
\hline $60 \%-70 \%$ & 0.2 & 0.2 & 0.2 \\
\hline $70 \%-80 \%$ & 0.1 & 0.3 & 0.1 \\
\hline $80 \%-90 \%$ & 0.1 & 0.2 & 0.1 \\
\hline $90 \%$ and above & 0 & 6 & 2 \\
\hline Total & 100 & 100 & 100 \\
\hline
\end{tabular}

Thirdly, the management mechanism is unscientific. The management organization is the link between the achievements supply inside the school and the market demands outside the school, and the management process is the information channel for the management organization to connect inside and outside the school. At present, there are many problems existing in the management mechanism, such as the strong administrative color of the management organization, lacking managing talents and the imperfect management system.

Fourth, the protection mechanism is not standardized. The not standardized mechanism of intellectual property protection is reflected in insufficient awareness of intellectual property protection, the imperfect intellectual property protection system and imperfect intellectual property protection institutions.

\section{The Intermediary Service System}

The intermediary service system in China has some problems, such as imperfect service system and lacking achievements evaluation mechanism. As for the number of intermediaries, intermediary service for S\&T achievements in China has experienced from scratch and some achievements have been achieved, but the total number is too small to meet the increasing demands for intellectual property services. As for the functions of intermediaries, most of the intermediary service organizations are single in function, imperfect in structure, and lack timely or accurate information services, which are far from meeting the increasingly rich demands for intellectual property services. As for the status and interests of intermediaries, the status of intellectual property service intermediaries is relatively vague at present, which cannot effectively play its important role in promoting the transformation of intellectual property, relevant policies related to intermediary service institutions such as results assessment agencies and intellectual property service agencies are still relatively scarce, intermediary service institutions are difficult to benefit from S\&T achievements transformation, and the construction of intermediary system is relatively weak.

\section{The financial service system}

The S\&T achievements transformation has the characteristics of high input, high return, high risk and long cycle. These characteristics make it difficult to obtain sufficient financial support through conventional business channels. Colleges and universities themselves do not have the financial strength of self-transformation; after weighing the returns and risks, enterprises keep away the high-risk technological achievements; the investment of government funds in S\&T achievements transformation is very limited; for the security of funds, financial institutions lack enough enthusiasm in some long-term and high-risk projects. Therefore, fund has become a bottleneck restricting the S\&T achievements transformation in colleges and universities, whether risk investment funds can be invested in S\&T achievements creating is an important link in the of success transformation. Current financial services in colleges and universities mainly include two modes: special funds and building the financial service system for intellectual property.

\section{E. The education and training system}

From the perspective of school education, there are problems, such as short supply of IPR talents, single type of IPR talents and insufficient internationalization of intellectual property transactions. The college of intellectual property of Peking University, established in 1993, has started independent colleges building, only a few universities have established independent intellectual property colleges and most universities have established intellectual property major under the law school. In curriculum setting, it is insufficient in researching and meeting the needs of countries along the "The Belt and Road Initiative", curriculum reform lags behind relatively, and the degree of internationalization needs to be improved.

From the social training, training methods mainly adopted at present include vocational qualification training and high-end practical training. Vocational training can effectively meet the demands for various intellectual property professionals, but it is not conducive to the cultivation of compound talents. High-end practical training is mainly aimed at high-end talents, can train high-level talents in intellectual property management for the society, effectively promote the continuous progress of intellectual property management, however, the number of talents trained is relatively small, which cannot meet the demands for high-end talents in intellectual property.

\section{Suggestions On the CONSTRuCtion of THE SERVICE SYSTEM OF INTELLECTUAL PROPERTY IN COLLEGES AND UNIVERSITIES}

\section{A. Building Professional Service Institutions for Intellectual Property Management}

Firstly, promote the professional development of intellectual property management services. Colleges and universities can promote the intellectual property management transforming into professional service model by learning from European and American experience. Intellectual property management institutions are set up within the limits of authority, and the IPR leading group is set up to coordinate the work on intellectual property in colleges and universities. The intellectual property management office under the intellectual property leading group is responsible for the daily work of intellectual property management in colleges and universities. Intellectual property management is a systematic project, managers shall look at the intellectual property management from a global perspective, and build a complete service chain from production to transformation and then to market value.

Secondly, implement differentiated management in daily management. Colleges and universities should carry out classified management, screen and evaluate patents, and give priority to the transformation of patents with developmental potential. Colleges and universities should clarify the functions and management details of intellectual property management institutions and their corresponding functional departments, 
with perfecting in administering by independent department, specially-assigned person for special post, rules and regulations refining, and coordination of operation mechanism.

\section{B. Establishing Collaborative Innovation Mechanism of School-Enterprise-Local Cooperation}

Explore the establishment of a collaborative innovation service model for school-enterprise-local cooperation. Colleges and universities should maximize the role of schools in a regional economy according to their own actual conditions and development needs of the national provinces and cities [5]. The S\&T achievements transformation is fully promoted by establishing modern university science and technology information distributing platform, and the comprehensive office for S\&T achievements transformation. Besides, colleges and universities should enhance cooperation with local governments, build diversified demonstration park of technology transfer based on regional pillar industries, build characteristic bases that integrates innovation and entrepreneurship practical training, technical research and development, and achievements incubation, so as to integrate the talents, science and technology, policies and resources of both sides.

\section{Overall planning and establishing the High-quality Talents Service System}

Intellectual property management talents should be compound talents with professional qualities in science, law, international trade, management and information retrieval, as well as good foreign language foundation, familiarity with international rules and patent operating skills. The government should encourage universities to actively carry out international cooperation and exchanges in intellectual property protection and management, select intellectual property protection and managers to study their advanced management concepts in developed countries, and build bridges for the achievements transformation in the world. Colleges and universities should pay attention to the cultivation of applied and practical intellectual property management talents according to the development and demands of the society, and take their own educational models with their own characteristics combing with their own advantages and resources.

\section{Building the Publicity Education \& Training System of Intellectual Property in Colleges and Universities}

At present, lacking corresponding training and education has become one of the important reasons for the general weak awareness of intellectual property in Colleges and universities. Therefore, it is necessary to strengthen training and education in intellectual property. Firstly, we should strengthen the training of intellectual property rights of leading cadres in Colleges and universities, and improve the management level and professional quality of scientific research managers. Secondly, we should increase the popularity rate of intellectual property training for teachers, in order to promote their independent innovation and the awareness of intellectual property protection. Finally, we should strengthen the experience exchanging and publicity in intellectual property training, and actively play the guiding role of propaganda.

\section{E. Cooperating to Build the Integrated Operating Service System for Intellectual Property}

Firstly, establish a special fund guarantee system for intellectual property. In matters related to patent application, maintenance of intellectual property, it usually needs sufficient funds to guarantee it. Therefore, it is particularly important to establish a system specifically for the protection of intellectual property funds to ensure that special funds are really used for the maintenance of intellectual property rights.

Secondly, explore ways to promote the mixed ownership reform of scientific and technological achievements tied to a position. Since 2015, Southwest Jiaotong University has jointly built a "Smart City around Southwest Jiaotong University" with Jinniu District and Chengdu, with clearing ownership of S\&T achievements as a breakthrough point, it has taken the lead in exploring the reform of the mixed ownership system of S\&T achievements in the country and formed a set of institutional mechanisms that can effectively improve the quality and efficiency of the S\&T achievements transformation, realizing the "three transformations" of scientific S\&T achievements transformation from "pure state ownership" to "mixed ownership", from "first transforming then confirming rights" to "first confirming rights and then transforming", and from "rewarding interests" to "transforming rights", which fully stimulates the enthusiasm and motivation of scientific researchers in innovation and creation, and lays a foundation for accelerating the transformation of S\&T achievements.

Thirdly, promote intermediaries to intervene in the industrial chain of intellectual property transformation in Colleges and universities. Colleges and universities should constantly improve and strengthen contacts with the social professional institutions such as media, legal consultants and consultants, market survey and research, arbitration and adjusting of interest disputes and other social professional institutions, so as to make all kinds of intermediaries aware of the potential achievements in colleges and universities, transform the treasury, enter colleges and universities actively, and promote the application of S\&T achievements of colleges and universities from transformation to industrialization.

\section{F. The government takes the lead in establishing intellectual property information exchange platform for provincial colleges and universities}

Abundant resources can improve the transformation efficiency of intellectual property, well-known universities at home and abroad all have large intellectual property exchange platforms and rich resources in the transformation of intellectual property. For example, enterprise cooperation committee of Tsinghua University has nearly 150 domestic members, nearly 40 foreign members, and the international technology transfer center of Tsinghua University has established very close cooperation with technology transfer institutions, trade associations, enterprises and universities in many countries, with abundant technical project resources, while ordinary universities often do not have such conditions. As a bridge between universities and enterprises, local governments take the lead in jointly establishing provincial university intellectual property information service centers together with provincial universities, build information 
mechanism of school-enterprise-land cooperation, overall

exchange platforms, supply-demand docking platforms and online service platforms, so as to promote innovation and transformation of S\&T achievements, and promote the regional economic development and improve the comprehensive competitiveness of local enterprises

\section{G. Strengthening the Construction of the Financial Service System of Intellectual Property in Colleges and Universities}

The financial service system of intellectual property rights in Colleges and universities is helpful to solve the funding problems faced by colleges and universities in S\&T achievements transformation. It is suggested that relevant departments formulate and implement relevant policies on finance, finance and guarantee, so as to promote the joint efforts of government finance, policy-oriented financial institutions and insurance institutions to support the S\&T achievements transformation in Colleges and universities, make up for the defects and deficiencies of market mechanism, and realize the sound development of the market for S\&T achievements transformation. We will promote the cooperation between financial institutions, enterprises and intellectual property Innovation Alliances in universities, realize the organic integration of the demand side, the supply side and the supply side of funds of intellectual property rights, and promote the transformation of intellectual property achievements.

\section{CONCLUSION}

From the perspective of system theory, this paper constructs the framework of service system of intellectual property in Chinese universities, analyzes the existing problems of the service system of intellectual property in Chinese universities based on this framework, and put forward some targeted solutions such as establishing professional intellectual property management service institutions and service modes, establishing collaborative innovation planning and establishing high-quality personnel service system, establishing the education \& training system for intellectual property publicity in Colleges and universities, establishing the integrated operation service system, and the government taking the lead in establishing the information exchange platform of intellectual property and strengthening the construction of the financial service system of intellectual property in colleges and universities.

\section{REFERENCES}

[1] Li Xirui. Construction and Improvement of Market-oriented Intellectual Property Information Service System in China [J]. Journal of Wuling, 2014(2):56-62. (In Chinese)

[2] Wang Guo. The Difficulties and Solution in Intellectual Property Transfer System in Colleges and Universities in China. Journal of Science, Technology and Law [J], 2018(4):73-86. (In Chinese)

[3] Liu Xiaojing. On the intellectual property management in Colleges and Universities [J]. China Management Informationization, 2015(3):192-193. (In Chinese)

[4] Zhao Yuhan, Wei Jiang, Wu Wei. The Difficulties and Solution of the S\&T Achievements Transformation in Colleges and Universities [J]. Research On Education Tsinghua University, 2017(4):108-116. (In Chinese)

[5] Huang Yipeng, Li Huajun, Wu Fan. Problems Analysis and Countermeasures of Intellectual Property Management in Colleges and Universities [J]. Science and Technology Management Research, 2011(11):142-146. (In Chinese)

[6] Zhao Zhe. The Practical Difficulties and Breakthrough of S\&T Achievements Transformation in Colleges and Universities in China [J] Journal of Higher Education Management, 2016(5): 52-56. (In Chinese)

[7] Zhou Ying. Problems and Countermeasures of Intellectual Property Talents Training under the New Situation [J]. Jiangsu Science and Technology Information, (3): 24-25. (In Chinese)

[8] Liu Dingcheng. On the S\&T Achievements Transformation in Colleges and Universities under the Perspective of "Internet Plus"[J]. Macroeconomic Management, 2017(A1): 231. (In Chinese) 